\title{
DOI https://doi.org/10.36059/978-966-397-241-1-12
}

\section{Мосякова І. Ю.}

кандидат педагогічних наук, заслужений працівник освіти України, докторант Мелітопольский дердавний педагогічний університет імені Богдана Хмельницького м. Мелітополь, Запорізька область, директор

Центр творчості дітей та юнацтва «Шевченківець» м. Київ

\section{ОСВІТНІЙ МЕНЕДЖМЕНТ: АКТУАЛІЗАЦІЯ ІДЕЙ УКРАЇНСЬКИХ І ЗАРУБІЖНИХ ВЧЕНИХ ДЛЯ ПРОФЕСІЙНОЇ ДІЯЛЬНОСТІ І ЗРОСТАННЯ КЕРІВНИКІВ ЗАКЛАДІВ ПОЗАШКІЛЬНОЇ ОСВІТИ В УМОВАХ АВТОНОМІЇ}

Проблема дослідження пов'язана із розкриттям сучасного виміру професійної діяльності директора закладу позашкільної освіти. Доведено, що освітній менеджмент у закладах позашкільної освіти $\epsilon$ науковою проблемою, в якій розкриваються основні підходи, теорії $i$ практики, нові лінії досліджень, що сьогодні потребують від директора якісного нового рівня управлінської культури. У підрозділі наголошено на нових умовах роботи закладів, підкреслено наявні проблеми, що пов'язані із новими тенденціями у освітній галузі. Результати дослідження доводять, що в сучасних умовах, що характеризуються розвитком мережевого суспільства, поширенням онлайн-освіти, активною фазою діджиталізації, дослідникам слід формувати нову систему знань про освітній менеджмент закладів позашкільної освіти, а директору закладу позашкільної освіти - переходити на нові технології та алгоритми освітнього менеджменту. Автор наводить низку вимог до професійних дій з боку керівництва, що зумовлене діджиталізацією, а також розкриває недоліки, які мають вплив на комунікацію у системі «педагог - керівник закладу позашкільної освіти». У підрозділі доведено, що для універсалізації професійних і особистих рис керівника важливо оволодіти новим розумінням професійної культури менеджера, де необхідним елементом постає готовність до формування культури автономізації закладу позашкільної освіти. 


\section{Вступ}

За останні роки у світі, де отримання нових знань, формування «жорстких» i «м'яких» навичок стало виграшною стратегією для підвищення якості життя, обговорюється зростання різноманітних концепцій щодо професійного розвитку керівників закладів освіти. У світлі уваги дослідників - і «внутрішнє» і «зовнішнє» поле діяльності керівників, зокрема: 1) вплив управління на педагогічних працівників організації; 2) вплив управління на всіх зацікавлених осіб у зростанні інтелектуальної, духовної Людини для суспільства (від лат. Ното ad societatem). Коли заклади освіти, зокрема, позашкільні заклади, впроваджують у життя освітній послуги, саме керівник закладу (а у позашкільних закладах освіти керівництво здійснює директор) має приймати рішення та реалізовувати корисні ідеї для покращання результативності освіти, звертаючи увагу на потреби і інтереси майбутніх поколінь. Такий керівник і педагогічна рада у закладах позашкільної освіти мають широке бачення та перспективи для зростання суспільного добробуту. В основному заклади позашкільної освіти, які не перший рік існують в Україні, як правило, допомагають задовольнити потреби та інтереси вихованців. При цьому директор закладу позашкільної освіти має системно, інтелектуально, етично та ефективно керувати освітнім процесом для того, щоб зробити додатковий крок для благополуччя суспільства.

У наш час заклади позашкільної освіти беруть на себе відповідальність щодо розвитку творчої особистості. Вони декларують запровадження освітніх інновацій, що змінюють мету, зміст, принципи, форми, методи педагогічної діяльності. Керівники у позашкільних закладах мають бачити ці процеси i, відповідно, мають володіти навичками оптимізації роботи педагогічних працівників. Також у педагогічних працівників має бути сформоване уявлення про те, що у цьому разі у виграші буде той заклад, який мінімізує обсяги непотрібної діяльності, використає нові обставини для покращення власної діяльності.

У даній роботі ми розглядаємо три основних теми, які допоможуть керівникам закладів позашкільної освіти оперативно реагувати на можливості і загрози, які з'являються у їх професійній діяльності:

1) освітній менеджмент: основні підходи, теорії, зміст і принципи діяльності керівника закладу позашкільної освіти;

2) особливості дій керівника закладу позашкільної освіти у мережевому суспільстві, що спрямовані на вирішення різноманітних педагогічних проблем;

3) створення культури автономізації закладу позашкільної освіти: алгоритми початку діяльності директора. 


\section{1. Освітній менеджмент у закладах позашкільної освіти як наукова проблема}

У наукових джерелах менеджмент $\epsilon$ однією із пріоритетних галузей суспільних наук. Менеджмент - велика частина роботи трудових колективів, у тому числі і педагогічних колективів багатопрофільних закладів позашкільної освіти. На сьогодні у таких закладах виникає багато питань, що потребують переосмислення і нового погляду з боку і керівників, і педагогів.

Пізнання освітнього менеджменту, проникнення до його сутності і специфіки $є$ предметом дослідження вчених різних країн. Так, Джон-Крістофер Спендер вказує на те, що інформація про генезу та розвиток менеджменту має два недоліки: «1) вони не здатні відрізнити управління бізнесом від інших видів управління та 2) вони частіше є історіями написання про менеджмент, ніж його здійснення» [21, с. 675].

Вважаємо, що сучасне бачення освітнього менеджменту вимагає уваги до специфіки природи управління тим закладом, у якого є своя історія, свій колектив працівників. У такому разі менеджмент має залежати від конкретних аспектів, що відрізняють сьогоднішне управління від управління у минулому. Удослідженні ми пропонуємо фокусуватися на вдосконаленні освітнього менеджменту у закладах позашкільної освіти, зокрема, на розкритті основних підходів, теорій, практик та сучасних технологіях управлінської діяльності в умовах автономії. Вважаємо, що дослідники освітнього менеджменту позашкілля мають зосередитися на виявленні сучасної системи знань, адже сучасним практикам не вистачає такого знання і саме тому досі у таких закладах існують прояви управління за бюрократичним режимом. Вважаємо, що бюрократична теорія для практики управління закладами позашкільної освіти не може бути адекватною, адже на часі - нові підходи, нові теорії та зміни у освітньому менеджменті.

Наше дослідження стосується і позицій впливу інформаційнокомунікаційних технологій на процес менеджменту. 3 цього приводу вкажімо на дослідження таких авторів, як Маріо Саба, Дєміен Брюте де Ремур, Сільві Жербе, які вказували на наявність дефіциту досліджень в галузі наук про управління. Автори зосереджують увагу на зв'язку організаційного інтелекту та використанні інформаційно-комунікаційних технологій в організаціях. Ми враховуємо думку авторів щодо різниці між поняттями «колективний інтелект» та «організаційний інтелект». Так, Маріо Саба, Дєміен Брюте де Ремур, Сільві Жербе 
зазначають: «під «колективним інтелектом» ми тимчасово маємо на увазі обмін інформацією за допомогою спеціальних інструментів. Під «організаційним інтелектом» ми маємо на увазі здатність вирішувати проблеми в групі людей шляхом співпраці» [20, с.47]. Тобто, в освітньому менеджменті позашкільного закладу інформаційнокомунікаційні технології мають впливати і на організаційний, і на колективний інтелект, адже керівник виконує не лише інформаційну, а й соціальну функцію.

Коли мова йде про основи управління закладами освіти в цілому, а не лише про заклади позашкільної освіти, можна вказати на те, що збільшення літератури 3 освітнього менеджменту (зокрема, навчальної) почало спостерігатися з кінця 1980-х років. Теми, на які була представлена така література, були досить широкими: самоврядування освітнього закладу, керівництво освітнім закладом, освітній маркетинг, вдосконалення управління школою, стратегічне управління людськими ресурсами в освіті тощо. Так, Хелен Гантер відмічала підвищення уваги до такої літератури, і вказувала на те, що цей період для керівників освітніх закладів і лідерів освіти був перехідним. Відмінністю освітнього лідера, який створює навчальні предмети, Хелен Гантер вважала забезпечення керівництва процесом створення нових предметів, організацію навчання для досягнення цілей та завдань. У директора освітнього закладу - інша мета, адже «саме директор несе відповідальність за покращення школи» [19, с. 29]. Автор також вказувала на те, що розуміння лідерів і лідерства в освіті пов'язано, насамперед, з виробництвом знань: «Хто це робить, що вони роблять, як вони це роблять і чому вони це роблять? Акцент робиться не стільки на продукті знання в формі факту або теорії, скільки на процесі, за допомогою якого відбувається вибір і організація з доступних знань в конкретний момент часу, який включає свідомий чи несвідомий вибір» [19, с. 5]. Отже, автор актуалізує проблему творення нового знання, а саме «виробництво знання» називає пов'язаним із структурою, яка здатна i спроможна контролювати процес творення знання. Працівників, які творять знання, автор ідентифікує як представників «розумової праці» і підкреслює, що зростання досліджень, що присвячені педагогіці лідерства, освітньому лідерству пов'язане 3 новою парадигмою, яка частіше використовується як засіб опису змін. Автор вказує на те, що знання знаходиться всередині епістемічних спільнот, адже наукове співтовариство пов'язане 3 професійною ідентичністю: «...зміна парадигми відбувається, коли 
епістемологічне співтовариство приймає новий спосіб мислення, бачення і визначення світу» $[19$, с. 6]. Такі зміни, за думкою автора, $\epsilon$ поступовими і рідко є продуктом однієї людини. Погоджуючись із автором, ми також вважаємо, що лідер позашкільної освіти і директор закладу позашкільної освіти мають різні функції. Інколи ці функції може виконувати одна особа, яка здійснює керівництво закладом, у інших випадках директор закладу має бачити таких лідерів, узгоджувати із ним позиції щодо змісту позашкільної освіти, що вимагає зведення правильного діалогу.

В Україні також спостерігається перехідний період у освітньому менеджменті, про що вказується у дослідженні I. Кушніра: «3 90-х років XX ст. в Україні поширюється ідея «знаходження свого обличчя». Вона втілюється в життя шляхом складання програми розвитку навчального закладу, в основу якої покладені конкретні принципи, засади організації освітнього процесу, ідеї, завдання. Такі підходи до моделювання навчально-виховних закладів несуть в собі величезні можливості щодо створення управлінської культури та розвитку педагогіки партнерства» [7, с. 28]. 3 погляду автора, саме всередині 90-х років XX ст. почалося вживання терміну «менеджер освіти», а самий освітній менеджмент розпочав фазу активного розвитку. I вже на початку XXI століття, як зазначав автор, «бажання, старанності та відданості гарного керівника XX століття, вже недостатньо» [7, с. 28]. Важливою вважаємо думку I. Кушніра про якісно новий рівень управлінської культури у закладах освіти, на формування якісно нових компетентностей у підготовці до керівної посади тощо.

Отже, поява великої кількості літератури із освітнього менеджменту свідчить про те, що у процесах управління освітою відбувається переосмислення саме на лініях лідерства, і на сьогодні для оновлення управлінських процесів необхідні якісні дослідження, які спрямовані на виявлення нових підходів, теорій, практик позашкільної освіти, яка базується на таких засадах, як лідерство, справедливість, якість, продуктивність. Наведемо з цього приводу думку Майка Боттері, автора книги «Виклики освітнього лідерства»: «Лідерство повернулося в моду. У багатьох західних країнах акцентується увага на поліпшенні потенціалу лідерства стосовно підвищення освіти і освітніх стандартів. Уряди всього світу беруть участь у перетвореннях освітніх реформ і приділяють велику увагу поліпшенню якості керівництва» [18, с. IX].

Управління позашкільним закладом освіти виходить із потреб суспільства. Незважаючи на те, що в освітній політиці існує 
впевненість у спроможності позашкільних закладів освіти забезпечити ії більш високу продуктивність, існують різні аргументи щодо інвестицій у позашкільну освіту, а отже, у освітнього менеджменту залишаються проблеми - збереження якісного педагогічного складу, збереження i розширення матеріально-технічної бази, розвиток інноваційного змісту освітніх програм, набір вихованців, учні, слухачів для їх введення у культуру суспільства тощо. I хоча виклики для сучасної позашкільної освіти є значними, а самий шлях до реформи $€$ доволі складним, потенціал керівництва по впливу на здобувачів позашкільних послуг і діяльності самого закладу залишається однозначним. У багатьох дослідженнях послідовно затверджується, що якість освітнього менеджменту має значення для розвитку мотивації педагогів та підвищення якості їх роботи із вихованцями. Саме менеджер освіти має знати, яким чином цілеспрямовано впливати на процес розвитку закладу, як перевести педагогічний колектив закладу на якісно вищу щабель, як, сприймаючі всі тонкощі людських почуттів, приймати та реалізовувати управлінські рішення, яку інформацію слід надавати для освітньої діяльності педагогів. У такому разі управління буде розумітися як процес, де отримують розвиток різноманітна діяльність суб'єктів позашкільної освіти. Від взаємопов'язаності даного процесу залежить реалізація управлінських функцій менеджера, які $\epsilon$ різноплановими, адже обумовлені нелінійністю, динамічністю.

У дослідженнях, що вивчають освітній менеджмент, увага прикута до культурних потреб суспільства, зазначається на відповідності діяльності закладів освіти до таких потреб. Так, Майк Боттері вказує на значну кількість ініціатив для розвитку освітнього менеджменту в різноманітних місцях по всьому світу, зважаючи на такі країни, як Канада, Велика Британія, Швеція, США, Сінгапур, Гонконг тощо. Автор вказує, що хоча всі ці місцевості $\epsilon$ різноманітними у відображенні місцевої культури та потреб, баланс відповідальності змінюється між урядом, місцевими органами влади та науковцями щодо вирішення проблеми освітнього лідерства. Майк Боттері вказує що відчувається недостатність розроблених програм для підготовки лідерів освітньої галузі, які мають не лише керувати закладами, а й створювати нове розуміння розвитку освіти. Автор вказує і на причину для такої діяльності: «Причину всієї цієї діяльності легко зрозуміти: у період масових змін $\epsilon$ нагальна потреба у всіх професійних вихователях, які мають зрозуміти ці зміни, щоб краще підготувати своїх учнів до різноманітності 
потенційного майбутнього» [18, с. 1]. Ми погоджуємося із таким твердженням і вважаємо, що саме Людина створює, зберігає, засвоює культуру, і в даному процесі задовольняються іï потреби - i матеріальні, і духовні, а життя усього нашого суспільства є складним процесом активної діяльності людей, які творчо осмислюють та перетворюють світ.

У сфері духовного життя людини головним завданням постає створення умов для самореалізації потенціалу людини, її духовнокультурного перетворення, примноження сутнісних сил, розвиток духовного світобачення тощо. У позашкільних закладах освіти доречним $є$ зважання на перетворення як духовного життя окремого вихованця, так і духовного життя суспільства в цілому. Позашкільна освіта $\epsilon$ духовною сферою, плекає духовні цінності, $\epsilon$ спрямованою на формування творчої особистості, яка здатна до саморозвитку, вдосконалення здібностей, розвитку наукового світогляду. Вкажімо на те, що статус позашкільної освіти визначено її спрямованістю на перетворення людини, адже саме у позашкільних закладах освіти проваджується у життя синтез знань про культуру, мистецтво, науку. Таке передання знань відбувається у часи дозвілля, але не кожна дитина, як підтверджують останні дані, $\epsilon$ спроможною сьогодні до розвивального навчання. Це призводить до викривлень розвитку і, відповідно, на це слід звертати увагу. Наведемо думку А. Бондар, М. Томанека, авторів монографії «Менеджмент позашкільних навчальних закладів фізкультурно-спортивного напряму»: «Слід зазначити, що найбільш популярними хобі $\epsilon$ заняття спортом (39\%), що в 4 рази перевищує художню самодіяльність і гру на музичних інструментах. Наступними за популярністю є художня самодіяльність (10\%), гра на музичних інструментах (10\%), вокальні гуртки (8\%), комп'ютерна графіка, програмування... тільки 44\% дітей віком 10-17 років мають можливість задовольняти свої потреби у дозвіллі на достатньому рівні. Для більшості опитуваних не вистачає коштів (70\%), вільного часу (26\%) та відповідних закладів за місцем їх проживання (26\%)» [3, с. 20]. Автори запевняють, що у сучасних дітей несформованими $\epsilon$ відповідні потреби, і наголошують на значному звуженні активного дозвілля в Україні: «14\% з них ніколи не займалися спортом, 34\% - не відвідують гуртки, 24\% - не відвідують театри та музеї, більшу ж частину вільного часу діти та підлітки віддають перегляду телевізійних програм, а кожен третій - комп'ютерним іграм» $[3$, c. 20]. 
На противагу особи, яка втрачає свій час на пасивне спостереження за іншими людьми, живе не у реальному, а у віртуальних світах, вільна особистість не лише сприймає нові знання, а й намагається творити самостійно, втілюючи у життя отримані вміння, рухатися, пізнавати світ. Саме тому управління позашкільною освітою одночасно виступає і як компонент соціалізації, що також суттєво впливає на осмислення питань, що вивчає освітній менеджмент.

Вважаємо, що управління позашкільним закладом освіти потребує від керівника цілісної системи знань стосовно різноманітних підходів до управління. Так, одним із важливих підходів вважаємо системний підхід. Для цього важливо розглянути, що таке системне управління закладом позашкільної освіти, якими $є$ закономірності розвитку і подальшого функціонування закладу, як мають бути співвіднесені основні частини управління між собою тощо. Таке теоретичне осмислення дозволить виявити, оцінити та детально проаналізувати існуючі протиріччя в процесі освітнього менеджменту як частини управління у соціумі, тобто, соціального управління.

Про те, що більшість організацій, де працюють люди, є системою, присвячено багато праць у сфері менеджменту. Так, вкажімо на думку Ч.Барнарда, який вказував, що організація $\epsilon$ не лише системою, а й такою системою, яка постійно змінюється. Така система, за його думкою, є координацією дій або сил і складається 3 пов'язаних між собою біологічних, психологічних і соціальних елементів. Для виживання, як писав Ч.Барнард, «організація повинна бути «ефективною» («effective»), тобто забезпечувати досягнення цілей організації, і «раціональною» («efficient»), тобто задовольняти особисті потреби учасників» [2, с. 6]. На думку вченого, керівник повинен погоджувати ці два процеси і виступати, як найменше, у двох ролях - як людина, що пов'язує організацію із зовнішнім середовищем, і людина, яка задовольняє особисті потреби членів організації.

Якщо розглядати освітній менеджмент закладів позашкільної освіти як специфічну системну управлінську діяльність, то слід виокремити у ньому загальні і специфічні принципи, основні i додаткові методи, технологічні прийоми, що спрямовані на ефективне функціонування закладу. Вкажімо на те, що освітній менеджмент позашкільних закладів освіти, як складова частина соціального менеджменту, відноситься до самостійної галузі 
наукового знання, в якому є об'єкт і предмет, функціональні зв'язки тощо. Відмітимо, що освітній менеджмент позашкільних закладів освіти має свій об'єкт - функція управління як специфічна діяльність керівника, яка має свої межі, а саме: діяльність суб'єктів закладів позашкільної освіти, що стосується надання і отримання освітніх послуг. Оскільки позашкільні заклади освіти не $\epsilon$ закритими організаціями, то об'єкт освітнього менеджменту може зводитися не лише до функції, а й до впливу на інші системи, зокрема, - освітні політики, культурні практики та різноманітні сфери життя людини. Визначальною у цьому плані $\epsilon$ теза про те, що збагачення $\mathrm{i}$ урізноманітнення суспільства залежить від того, яким чином воно організує передання своїм громадянам багатства і різноманітності не лише шкільної, а й позашкільної освіти. У свою чергу, збагачення і урізноманітнення позашкільної освіти досягається лише у тому випадку, коли розгортаються культурно-освітні практики, які спрямовані на досягнення різних цілей. Ми вважаємо, що всі різні цілі у роботі позашкільних закладів освіти $є$ взаємопов'язаними між собою. У тому випадку, якщо на сьогодні домінантою виступає лише одна із цілей, то вона не надає можливості досягти інші цілі, що викривляє гармонійний розвиток людини.

Тільки тоді, коли педагоги різних профілів навчання будуть мати різні ідеї стосовно процвітання суспільства, збагачення як окремих людей, так і певних груп (у тому числі людей, які мають особливі освітні потреби) то, відповідно, вони мають право впливати на процес прийняття рішень. Закономірність буде виглядати у цьому разі таким чином: ефективність управління позашкільним освітнім закладом є залежною від застосування різноманітних ідей, нових підходів та досягнень різноманітних наук, різних видів мистецтв тощо. Підкреслимо, що у системі знань керівника у цьому плані мають бути і нові досягнення у різних мистецтвах, а також у таких науках, як філософія, культурологія, соціологія, педагогіка, психологія тощо. Також додамо, що на зміну філософії «тиску» (у тому числі адміністративного) приходить філософія партнерства i співробітництва. Необхідними рисами теорії освітнього менеджменту закладу позашкільної освіти $\epsilon$ поступове доповнення теоріями соціального управління, теорією менеджменту закладами загальної середньої освіти, теорією освітнього лідерства тощо. Вважаємо, що осмислення цих ідей, їх перенесення до закладів позашкільної освіти мають відкривати об'ємний простір для розробки самостійного відгалуження в освітньому менеджменті - 
освітнього менеджменту позашкільних закладів. Такий освітній менеджмент $є$ новою галуззю знань, адже вимагає філософської, соціально-педагогічної, психологічної рефлексії, проведення соціологічних досліджень, фокус-груп із керівниками закладів позашкільної освіти, які мають різні пропозиції та різні уявлення про освітній менеджмент в умовах автономії.

Вважаємо, що йдеться про зміну парадигми освітнього менеджменту, в умовах переходу людства до цінностей, серед яких значущими $\epsilon$ цінності автономії, незалежності, самостійності. У такому випадку сутність роботи керівника закладу позашкільної освіти буде торкатися питань ціннісно-смислових впливів на педагогів різних профілів для того, щоб організувати або скорегувати їх професійну поведінку, звести більш досконалі взаємовідносини із здобувачами позашкільної освіти із врахуванням принципу суб'єкт-суб'єктних відносин.

Вкажімо на відмінність менеджменту освіти і освітнього менеджменту позашкільних закладів. Так, освітній менеджмент позашкільних закладів пов'язаний із діяльністю педагогів, більшість яких працюють із дітьми у їх дозвіллєві часи. Дана діяльність не є жорстко регламентованою, адже, як вказують А. Бондар, М. Томанек, головною метою закладів позашкільної освіти $\epsilon$ «сприяння гармонійному розвитку особистості, соціалізація дитини або молодої людини у суспільстві, вилучення її з вулиці та задоволення потреб у відпочинку та самореалізації» [3, с. 23]. Поняття «менеджмент освіти» $є$ більш широким і, як вказує О. Мармаза, тлумачиться таким чином: «Менеджмент освіти - це вид управлінської діяльності, який складається із сукупності засобів, методів та форм впливу на індивідуумів та колективи з метою ефективного функціонування даної галузі» [9, с. 12].

Освітній менеджмент позашкільних закладів розглядає педагога як суб'єкта управління, який виконує наставницьку функцію, адже педагог у закладах позашкільної освіти орієнтований, насамперед, на досягнення розвитку особистості вихованця, слухача, набутті ними спеціальних компетенцій. У цьому плані наголосимо, що керівник позашкільного закладу має бачити з позицій системи всю освітню організацію, ïï зв'язки, адже розумні управлінські рішення приймаються на основі системи знань і системного бачення специфіки діяльності закладу.

Освітній менеджмент позашкільних закладів і менеджмент освіти мають і загальне, і особливе. У загальному сенсі це можна 
схарактеризувати як вплив на особистість, яка знаходиться у полі зору керівника. Освітній менеджмент позашкільних закладів безособовий вплив ідей, різноманітних концепцій на вільний розвиток особистості, із урахуванням їі інтересів і уподобань, де педагогіка партнерства $€$ визначальною умовою для функціонування закладу в цілому.

Менеджмент освіти перед собою бачить різні види управлінської діяльності у різних сферах - фінансовий, інноваційний, соціальний, правовий, адміністративний тощо. Ці сфери пов'язані між собою і у повсякденній діяльності керівника їх складно виокремити. Освітній менеджмент позашкільних закладів спрямований на суб'єктів позашкільної освіти, якість освітніх послуг, а отже, його здійснення залежить від чинників, що стосуються профілю позашкільного закладу, особистісних характеристик педагогічних працівників і здобувачів позашкільної освіти, і, відповідно, особливих умов, які створені для занять відповідного профілю.

Наприклад, якщо мова йде про фізкультурно-спортивний профіль, тут особливістю буде керівництво системою дозвіллєвої діяльності дітей та молоді в позашкільних навчальних закладах фізкультурноспортивного напряму, до яких відносять спортивні клуби, станції, гуртки, секції, дитячо-юнацькі спортивні школи, спортивні клуби за місцем проживання тощо. У цьому плані специфічним буде те, як керівник цього закладу розглядає питання розвитку матеріальної бази для різних видів спорту, яким має бути стан нормативного забезпечення, як має відбуватися тренувальний процес, як має здійснюватися кадрові питання, які існують нові напрями для подолання різноманітних недоліків організаційного характеру тощо. Такими недоліками, за думкою А. Бондар, М. Томанек, є: «невелика кількість виховних заходів, які не координуються між собою і не завжди доцільні... недостатні педагогічно організовані контакти вихованців закладів із досвідченими спортсменами та видатними тренерами» [3, с. 26-27]. У роботі вказано на те, що у педагогічного персоналу таких закладів майже відсутній педагогічний контакт 3 батьками вихованців, і це свідчить, як вважають автори, «про необхідність поліпшення організації виховного процесу в системі фізкультурно-спортивних організацій, яке б дало змогу більш повно реалізувати значний педагогічний і виховний потенціал спортивної діяльності під час занять юних спортсменів...» [3, с. 26-27].

Отже, будь який заклад позашкільної освіти має відповідні складнощі організаційного порядку і саме тому універсальних рецептів управлінської діяльності для кожного не може існувати. 
У структурі нашого дослідження відведено увагу принципам освітнього менеджменту позашкільних закладів. Назвемо основні принципи, за якими здійснюється управління у закладах позашкільної освіти, що продиктовані державною політикою України. Ці принципи вміщено у Законі України «Про позашкільну освіту», зокрема, у статті 9, а саме: доступність позашкільної освіти для громадян України; добровільність у виборі типу закладів позашкільної освіти, а також різноманітних форм позашкільного навчання і видів діяльності; науковість; світський характер освіти (у державних і комунальних закладах позашкільної освіти); правовий і соціальний захист вихованців, учнів і слухачів в їх прагненні до вільного, різнобічного розвитку особистості тощо [11]. Додамо до цих принципів і специфічні принципи управління позашкільним закладом, а саме: принцип стратегічного інвестування у новітні педагогічні технології, принцип креативності у розробці нових освітніх програм для позашкільної освіти, що потребує наукового підгрунтя. Зважаючи на перший специфічний принцип, слушною $\epsilon$ думка Л.Рижак: «справжніми лідерами цивілізаційного поступу у двадцять першому сторіччі будуть ті нації, які стратегічно інвестуватимуть у науку й технології» $[13$, с. 6].

Основні положення, що стосуються принципів управління позашкільним закладом освіти, мають бути відомі директору як особі, що повсякденно здійснює керівництво закладом. Виходячи із такого розуміння загальних і специфічних принципів управління, вважаємо, що у позашкільних закладах освіти на рівні стосунків «директор-педагог», «директор-педагогічна рада» присутнім $\epsilon$ психологічний аспект, який слід розглядати через призму існуючих технік взаємодій людей між собою, в основі якої лежать цілісні теорії психологічного знання, які використовуються під час розробки методології управління закладом. Можемо вказати на «відкритий психологізм» в управлінні, який, як на нашу думку, розкривається у мовленнєвому зверненні директора закладу до підлеглих i «закритий психологізм», які передається через деталі, ситуацію, випадки, що стають по відношенню до одного й того ж працівника закономірностями. Не кожне закрите повідомлення носить цілком адекватний характер, оскільки може мати під собою маніпулятивні техніки взаємодії, що вносять у професійну діяльність педагога вразливість і розгубленість Це, звісно, не сприяє підвищенню якості позашкільної освіти. Безперечно, таке ставлення призводить до нівелювання найкращих особистих рис людини, адже у такий спосіб 
подолати хаос у почуттях, що виникають від такої взаємодії, для педагога дуже складно.

I керівники, і педагоги, що задіяні у наданні послуг у сфері позашкільної освіти, розуміють, що нова епоха поступово змінює пріоритети. У такому плані стають важливими такі цінності: благополуччя (економічне, соціальне, емоційне тощо) i мирне співжиття у всіх сферах - міжособистісній, професійній, сімейній тощо. Для плекання цих цінностей потрібні нові парадигми і системи точних, вивірених знань, ефективний обмін інформацією i комунікація. У цьому світлі розвиток аксіології, як вчення, в якому з'являються нові уявлення про смисли і цінності життя, є важливим для функціонування раціональної i, водночас, людинолюбної ідеології. Сукупність таких аксіологічних ідей у роботі із педагогами, які розкривають сутнісні сили вихованців, надають їм можливість творчо виявити себе, складають нову ідеологію для пошуку концепції освітнього менеджменту закладів позашкільної освіти у XXI столітті. Вважаємо, що на тлі таких ідей буде забезпечено вирішення у теоретичному та практичному вимірах проблему подолання негативних впливів на людину, яка бажає змінити себе i оточення, реалізовувати себе у різних видах творчості, відривати сутнісне «Я». Тому закономірною є пропозиція щодо творення такої концепції для подолання людини деформованої, дії якої - профанні, а думки - асоціальні. Як на нашу думку, така концепція має розкрити принципово новий тип керівника закладу позашкільної освіти людинолюбного професіонала, знавця основних позицій освітнього менеджменту, творця нових норм діяльності. Такий професіонал діє, орієнтуючись на базові цінності суспільства, досягає загальної мети, прямує за власним покликанням. Таке управління має ліберальні риси, але не позбавлене чіткості у досягненні цілей діяльності, раціональності у досягненні високих стандартів. Можна уявити, що заклади позашкільної освіти одними із перших нададуть таких керівників, адже у таких закладах атмосфера $\epsilon$ найбільш вільнолюбною через турботу про інтереси людини. У цьому плані зважимо на поширення у європейських країнах ліберальної педагогіки, в основі якої - самоврядування, вивчення «вільних» мистецтв.

Ліберальні позиції підсилює аксіологічна модель зведення системи управління закладами позашкільної освіти. У цьому світлі слід звернути увагу і на нові напрями відтворення колегіальності, колективності, солідарності, що на сьогодні постає одним із 
перспективним у педагогічній науці. Вважаємо, що ліберальні погляди на позашкільну освіту мають певну привабливість, адже саме лібералізм надає можливість розвинутися автономності, незалежності, що створює простір для розгортання свободи. В межах ліберальних традицій можна побачити тенденцію розвитку автономності, що впливає на свободу діяльності у позашкільній педагогіці, що створює простір для відтворення свободи творчості, розвиток дитячих і молодіжних рухів тощо.

\section{2. Культура автономізації закладів позашкільної освіти у становленні мережевого суспільства}

На процес професійної діяльності та зростання керівників закладів позашкільної освіти мають великий вплив такі сучасні тенденції, як глобалізація, інформатизація, автономізація. Це, у свою чергу, спричинює певні наслідки. До них ми можемо віднести: усвідомлення важливості професійної мобільності кадрового складу педагогів; уніфікація процедур, пов'язаних із наданням освітніх послуг за допомогою дистанційних технологій; посилення уваги до самобутності авторських програм, їх унікальності тощо. Вважаємо також, що ці питання потребують нового погляду на теорію та практику освітнього менеджменту у закладах позашкільної освіти, адже робота у даному напрямі вимагає від керівників абсолютно нових рішень, нових методів управління. Така робота має охопити всю глибину взаємодії керівника і педагогів, які поступово переходять від інформаційного суспільства до мережевого суспільства і концентруються не лише на збільшенні об'єму інформації для проведення якісної педагогічної роботи, а й на кластерізації груп споживачів освітніх послуг, які бажають отримати соціальні, економічні та інші переваги для покращання якості життя.

Підкреслимо, що на сьогодні $\epsilon$ очевидним факт, що мережеві світи самі по собі не можуть гарантувати якісної управлінської діяльності, спільної командної роботи педагогів у напрямі підвищення якості освітніх послуг для здобувачів позашкільної освіти. Мережевий світ лише виступає одним із інструментів комунікації. Врахуємо існування такого поняття, як «становлення мережевого суспільства» (I. Сопілко [15]). Автор вказував, що таке суспільство є вищім, ніж інформаційне суспільство і саме в межах мережевого суспільства популярності набуває мережева комунікація. Дана комунікація, як вказує вчений, виражається у зростанні числа соціальних Інтернетмереж, які надають додаткові можливості. Наведемо його вислів: 
«Підгрунтям формування мережевого суспільства стало розроблення у кіберпросторі соціальних мереж: мереж, які за допомогою запропонованих алгоритмів визначають спільні інтереси, здійснюють пошук і фактично формують замкнений і цікавий світ для конкретної людини: починаючи від ії інтересів у книжках, закінчуючи привілеями щодо спілкування з тими чи іншими особами за фаховими й іншими ознаками. У рамках цих мереж людина отримує нове реальне життя з реальними привілеями та перевагами перед іншими - не членами конкретної мережі» [18, с. 81].

Про потребу нашого суспільства в розбудові мережевих структур для інноваційного розвитку освіти йдеться у монографії «Організаційно-педагогічні засади діяльності та тенденції розвитку інноваційних шкільних мереж Великої Британії та США» [Сбруєва, 2019, c.5]. Автори доводять, що така проблема $€$ предметом вивчення різних наук, серед яких освітній менеджмент займає чинне місце. Автори вказують: «Теоретичні засади діяльності інноваційних шкільних мереж розглядаємо в контексті теорій мережевого суспільства (Б. Велман, Я. ван Дійк, М. Кастельс та ін.), мережевого менеджменту (М. Хадфілд та ін.), теорії інноваційних шкільних мереж (Х. ван Аальст, С. Дей, Д. Джексон, Т. Кантвел, Д. Хопкінс та ін.)» $[14$, c. 10$]$.

Такі мережі взаємодіють між собою, переплітаються, і в майбутньому, як на нашу думку, будуть розвиватися у нові віртуальні світи. Для такої взаємодії керівнику потрібно враховувати і появу мереж у двох напрямах: 1) нові мережі комунікацій між людьми, що забезпечують різноманітні інформаційні сервіси; 2) нові науковотехнічні розробки, в яких систематизуються різноманітні дані для аналітичної роботи.

У якості прикажу першого напряму назвемо Міжнародну асоціацію позашкільної освіти, яка для таких закладів надає інформаційну підтримку, організовує і проводить конференції, семінари, круглі столи, сприяє узгодженню освітньої політики у цьому напрямі, здійснює вплив на органи самоврядування тощо, організовує інформаційні кампанії 3 підтримки і збереження закладів позашкільної освіти у територіальних громадах тощо. Це мережа, яка забезпечує якісну взаємодію між людьми, інтереси яких збігаються у напрямі позашкільної освіти.

Для прикладу другого напряму можемо назвати нову розробку програмно-апаратного комплексу «Автоматизований інформаційний комплекс освітнього менеджменту», метою якої $\epsilon$ «забезпечення 
можливості використання суб'єктами освітньої діяльності електронних сервісів для ефективного управління закладом освіти у дошкільній, загальній середній, позашкільній та професійній (професійно-технічній) освіті» [10]. Так, у Постанові Кабінету Міністрів України (від 08.07.2021) актуалізовано появу такого комплексу таким чином: «Остатніми роками в Україні відбувається стрімкий розвиток новітніх інформаційно-комунікаційних технологій та створення освітніх електронних інформаційних ресурсів, що відкрило можливість переведення документообігу в електронний формат, зменшення адміністративного навантаження на заклади освіти та в перспективі - повністю відмовитися від збирання, зберігання та подачі паперових документів в закладах освіти» [10, с. 15]. Також важливим $\epsilon$ визначення ключової функції програмно-апаратного комплексу «Автоматизований інформаційний комплекс освітнього менеджменту» в розбудові системи електронного документообігу у закладах дошкільної, загальної середньої, позашкільної та професійної (професійно-технічної) освіти. Так, у документі наголошено, що такий комплекс $є$ системою класу EMIS (Education Management Information System, електронна система управління освітою) [10, с. 15].

Отже, ми бачимо бурхливий розвиток мережевого менеджменту в освіті, що на сьогодні характеризується прискореним створенням нових мереж для структуроутворювального суспільства, в якому створення інформаційних подій, обробка інформації для прийняття рішень та передання рішення до виконання стають основними джерелами здійснення керівництва. У системі закладів позашкільної освіти розбудова різноманітних мереж на часі, адже в своїй основі така комунікаційна структура має містити не просто інформацію, а інтелектуальну мережу для системної переорієнтації педагогічної праці, яка має творчий характер.

На нашу думку, така переорієнтація може застосовуватися до різних видів інноваційної діяльності, а саме: нові авторські програми i посібники до них, що можуть бути розташовані на спеціальних ресурсних платформах, нові процеси методичного супроводу для засвоєння нових компетенцій і специфічних навичок; нові методи роботи із батьками та особами, що їх замінюють тощо.

3 огляду на це звернемося до думки М. Кастельса, який обгрунтовує думку стосовно нових джерел креативності, які з'являються в сучасному світі. За його думкою, такі джерела містить технологія генерування знань, обробка інформації, символічна комунікація 
тощо [6, с. 39]. Згідно з теорією М. Кастельса, сила мереж - у їх гнучкості, самоналаштуванні та адаптивності. Проводячи порівняння із командно-адміністративною структурою управління, М. Кастельс стверджував, що за розміром, складністю та обсягом потоків такі мережі виявляються менш ефективними. Однак поступова трансформація комунікаційних технологій мережі розширяють можливості для виконання управлінської функції, що потребує більш детального вивчення основних дій, які притаманні ролі керівника. У книзі «Влада комунікації» М. Кастельс задає запитання: «Де знаходиться влада в глобальному мережевому суспільстві?» і поступово пояснює, що існують чотири конкретні форми влади, а саме: мережева влада, влада мережі, влада в мережі, влада, що створює мережу [5, с. 60]. Автор наводить такі приклади найвищої форми влади у мережевому суспільстві: «У світі мереж можливість здійснювати контроль над іншими визначають два основні механізми: здатність створювати мережу (мережі) i програмувати / перепрограмувати роботу мережі (мереж) для досягнення поставлених перед мережею цілей і здатність з'єднувати і забезпечувати взаємодію різних мереж на основі поділюваних загальних цілей і об'єднання ресурсів, запобігаючи при цьому суперництву 3 іншими мережами за допомогою формування стратегічної взаємодії» [5, с.63]. Першу владну позицію автор відводить «програмістам», а другу владну позицію - «перемикачам». М. Кастельс пояснює значення таких владних ролей і доводить, що влада тут належіть не одній людині, а цілій групі людей, які у сукупності володіють різними знаннями. Тобто, враховуючи ці думки, вважаємо, що для створення мережі, в якій буде можливою комунікація для представників закладу позашкільної освіти, необхідно забезпечити представників освітнього менеджменту і програмістів знаннями і, відповідно, способами артикуляції цілей навчання і виховання для того, щоб у майбутньому кожний педагог, як користувач мережі, мав можливість презентувати себе, продемонструвати свої компетентності на відносно стабільній платформі. Тут не йде мова про створення мережі для спілкування між працівниками закладу позашкільної освіти. Тут найважливішим постає «колективний інтелект» і «організаційний інтелект», їх взаємодія, в основі яких мають бути закладено широку палітру цінностей - і матеріальних, і духовних.

Для нашого дослідження актуальною є думка М. Кастельса про бажання людини бути більш автономною, і наводить дані про те, що 
саме Інтернет $є$ тим інструментом, який надає можливість бути більш автономним: «3 одного боку, - вказує М. Кастельс, - зростає число людей, особливо молодих, які стверджують свою автономність по відношенню до інститутів суспільства і традиційних форм комунікації ... 3 іншого боку, поширення Інтернету і бездротової комунікації підтримує і зміцнює практики автономії, включаючи вироблений користувачами контент, який завантажується в Інтернет. Наприклад, ... було виділено шість різних статистично незалежних показників автономії: особиста, підприємницька, професійна, комунікативна, соціополітична і тілесна... Ми виявили, що чим вище рівень автономії, тим вище частота та інтенсивність користування Інтернетом. І чим більше люди користуються Інтернетом, то більше вони збільшують свій рівень незалежності» [5, с. 154].

Додамо також і думку О. Барда та Я. Зодерквіста, які вказували на роль самостійності і незалежності людини у пошуку і віднайдені інформації, яка дозволяє здійснювати комунікацію без будь-яких вказівок. Автори свідчать і про появу нового типу людини, - дівідууму, який має у мережі безліч ідентичностей: «У Мережі ідентичність людини буде проявлятися тільки у поточному контексті з тим, щоб в наступний момент зазнати зміни, що захоплюють дух. Індивідуум, людина цілісна, йде геть, вона прикута до своєї одноманітності, як до важкого рюкзака, на її місце приходить дівідуум, людина багатолика. На першій стадії людина багатолика перестане намагатися бути людиною, на другій для неї стане неможливим стати людиною знову, як би вона цього не хотіла. Ця нова свобода і приваблює, і лякає одночасно, але вона неминуча» [1, с. 188].

Отже, у мережі керівник стикається із різними питаннями, що до сьогодні видаються не вирішеними і саме тому для професійної діяльності і подальшого розвитку важливими $є$ ті інституції, які віднайдуть більш швидкі та зручні сервіси, які сприятимуть самонавчанню, будуть здійснювати супровід професійного зростання вільної людини, використовуючи інструмент Інтернету та віртуальні платформи.

Роль менеджменту у зведенні нових освітніх послуг важко переоцінити. Нові освітні послуги у цьому випадку стають ефективним соціальним ліфтом, що дозволяють швидко зростати і як особистість, і як професіонал.

Використовуючи ідеї А. Сбруєвої, І. Чистякової, Ю. Самойлової, розглянемо можливості мережевого суспільства для позашкільної 
освіти. Власне, про позашкільну освіту автори говорять досить мало, але, розглядаючи їх ідеї, можна простежити, які наслідки інноваційні шкільні мережі можуть мати для позашкілля.

Автори, грунтуючись на системному підході, розглядають інноваційну шкільну мережу як складну, відкриту систему, яка не контролюється із єдиного центру. Вони вказують на те, що така мережа $\epsilon$ «новою формою організації процесу навчання, яка для досягнення спільної мети використовує нові методи, засоби та прийоми навчання, упроваджує в освітню практику принципово нові моделі управління закладами освіти (мережевої, дистрибутивної, екзекутивної, кооперованої)» [14, с. 44].

Розгляньмо більш детально мережеву модель управління закладами освіти. Така модель найбільш повно представлена у роботі I. Чистякової, яка розглядає інноваційні освітні мережі як, насамперед, «організаційні структури, що являють собою сукупність навчальних закладів, об'єднаних спільною інноваційною ідеєю та діяльністю, спрямованою на підвищення ефективності навчально-виховного процесу та якості його результатів, управлінської діяльності, а також на поширення інноваційного досвіду в межах мережі навчальних закладів і поза нею» [17, с. 57]. Автор наголошує на тому, що управління такими мережами $є$ незалежним від адміністративних розпоряджень. Водночас для ефективного функціонування таких мереж автор вважає доцільним застосування принципів стабільності, зрозумілості, впровадженні деяких форм організаційного керівництва: «У цьому значенні будь-яка існуюча мережа передбачає таку форму адміністративної та управлінської структури, яка ініціює процес фактичного мережування, формулює принципи діяльності й керівні принципи для членства, створює інфраструктуру зв'язку, залучає учасників, а також сприяє постійному обміну між ними» $[17$, c. 57]. Автор вказує на спільні риси управління такими мережами: «множинність лідерів; об'єднувальна мета; добровільність зв'язків; множинність рівнів взаємодії; відкритість, спонтанність; неієрархічність, децентралізація, переважно горизонтальна або функціональна кооперація учасників; відкритість мереж для «входу» та «виходу», загальнодоступність ресурсів (передусім інформаційних); рівноправність учасників мережі незалежно від їх ролі, масштабу, ресурсів; висока мобільність; консенсусність ухвалення рішень; чітка організаційна структура» $[17$, с. 60$]$.

Важливо розуміти в цьому контексті особливості діяльності менеджера закладу позашкільної освіти. У мережевому суспільстві 
його діяльність буде мати декілька напрямів: 1) вплив на процеси формування ідентичності педагогів закладів позашкільної освіти із врахуванням існуючої тенденції появи дивідуумів; 2) робота над іміджем закладу позашкільної освіти як у матеріальному, так і у віртуальному світах; 3) акцентуація смислів щодо обрання ефективних освітніх стратегій для отримання компетентностей, розвитку творчого мислення, формування навичок творчої діяльності для здобувачів позашкільної освіти; 4) керівництво інформаційними потоками як між представниками закладу позашкільної освіти, так і представниками інших установ, інституцій, що мають вплив на якість надання освітніх послуг тощо.

Позашкільна освіта, як сфера освітнього, культурного обміну, $є$ системою, що транслює знання. Кожен вихованець, який хоче навчитися новому, може отримати доступ до навчання за умови існування мережі Інтернет. У цій мережі доступними $€$ більшість інформаційних повідомлень, текстів для проведення дозвілля, для набуття нових професійних навичок. Саме тому керівнику позашкільного закладу освіти слід змінити свою позицію і навчитися управлінню інформаційними потоками, вміти прогнозувати події та організовувати їх із урахуванням потреб здобувачів.

У контексті нашого дослідження вважаємо за необхідне звернутися до праці Л. Тихенко, в якій обгрунтовуються головні напрями діяльності з впровадження інформаційно-комунікаційних технологій у позашкільній освіті. Автор вказує на основні причини, що гальмують процеси використання інформаційно-комунікаційних технологій педагогами закладів позашкільної освіти. Так, наведемо таку думку: «Серед причин, що стримують використання інформаційно-комунікаційних технологій у навчально-виховному процесі у позашкільних навчальних закладах, $€$ психолого-педагогічні проблеми, які полягають у відсутності: науково обгрунтованої методики використання інформаційно-комунікаційних технологій під час проведення занять у гуртках та інших творчих об'єднаннях; системи організації психологічного супроводу та методичної роботи в закладі щодо використання сучасних інформаційно-комунікаційних технологій; ефективного механізму накопичення, узагальнення та поширення передового досвіду використання інформаційно-комунікаційних технологій в освітній діяльності позашкільних навчальних закладів; цілеспрямованої роботи 3 формування інформаційної культури в суб'єктів навчальновиховного процесу» $[16$, с. 371$]$. 
Такі ідеї, що виголошені автором, потребують не лише психологічного супроводу, а супроводу, насамперед, організаційного, в якому має бути закріплений принцип безальтернативності зростання і розвитку суб'єктів позашкільної освіти у мережевому суспільстві, що передбачає оновлення технологічних складових процесу управління. Наша думка $\epsilon$ суголосною із тезою, що проголошена у дослідженні О. Просіної. Зокрема, автор вказує на оновлення інструментарію для директора позашкільного закладу, необхідності стратегічного планування роботи закладу в умовах пандемії. Зокрема, автор вказує на слабкі місця для роботи позашкільних закладів освіти в умовах пандемії, що зумовлює перегляд роботи керівника. Так, наведемо ії̈ думку: «Існують реальні загрози закриття закладів, що може бути вирішено за підтримки громад та держави. Серед слабких сторін дистанційного навчання виявлено проблему формування практичних та соціальних компетентностей. Важко в умовах онлайн освіти відтворити яскраве, привабливе поле діяльнісних практик та експериментів вихованця під безпосереднім наставництвом педагога. Театральні, спортивні, хореографічні, музичні та інші гуртки потребують фізичного відвідування майстерні» [12, с. 150-151]. В той же час 0.Просіна підкреслює існування нових можливостей у роботі закладів позашкільної освіти, які необхідно використовувати у подальшій діяльності. До таких можливостей вона відносить: «І вихованці, і педагоги мають потужну мотивацію розвиватися за допомогою IT-технологій, не виходячи 3 дому. Пізнавати нові технології комунікацій та передачі знань на відстані (фото, відео, онлайн майстер-класи, участь і проведення заходів і т. д.). Розвиток онлайносвіти допомагає стати доступним навчання для людей 3 обмеженими фізичними можливостями. Дистанційна освіта забезпечує безперервність освітнього процесу під час незвичайних ситуацій, карантину, інших обставин» [12, с. 151].

Погоджуючись із автором, вкажімо на те, що освітній менеджмент у мережевому суспільстві характеризується відкритістю, гнучкістю, адже зміни, які відбуваються у позашкільній освіті, зорієнтовані на культуру автономізації як самого закладу позашкільної освіти, так і на автономію педагогів, на їх творчу ініціативу, свободу у виборі методів навчання, а в останні часи - вільний вибір онлайн-платформ для роботи із вихованцями. Лише грунтуючись на культурі автономізації, можна сформувати позашкільний заклад, який буде успішно діяти у вимірі різноманітних інформаційних потоків і в 
умовах пандемії. I тут завданням керівника є забезпечення ефективної діяльності педагогів в інформаційній сфері. Підкреслимо, що це висуває низку вимог до професійних дій з боку керівництва, саме: 1) створення та/або оновлення концепції діджиталізації та інформатизації закладу позашкільної освіти; 2) розробка комплексної програми реалізації заходів, що представлені у концепції (організаційний, матеріально-технічний супровід, забезпечення програмної підтримки тощо); 3) організація навчання педагогів ефективно використовувати нові форми і методи навчання, дистанційні технології у роботі із вихованцями; удосконалення цілепокладання, організації, контролю за освітнім процесом, в основі якого - інтеграція традиційних та інноваційних методів управління; 4) розгортання інформаційного простору для провадження культурно-освітніх практик у роботі закладів позашкільної освіти тощо. При цьому ми вважаємо, що абсолютизувати діджиталізацію у процесі управління не потрібно, адже крім переваг, потрібно мати на увазі й недоліки, до яких нами віднесено: 1) розмивання часових меж, що змушує здійснювати у вільний час професійні обов'язки, а у вільний час, який має бути спрямований на задоволення особистих потреб, здійснювати робочі «візити» та спілкування на теми, що потребують «негайного» вирішення; 2) ненормоване використання інформаційно-комунікаційних технологій, що впливає на стан здоров'я - і фізичного, і психічного; 3) надмірна активізація у відстеженні нових тенденцій, нового змісту, форм і методів навчання, що мають вплив на систему позашкільної освіти. Вважаємо, що такі недоліки мають вплив на комунікацію у системі «педагог - керівник закладу позашкільної освіти» і потребують із боку керівника пильної уваги.

У дослідженні ми не можемо обійти питання готовності керівника позашкільного закладу освіти до формування культури автономізації, яка $є$ елементом його професійної культури. Така культура поступово входить до життя людини, надає їй нові, специфічні риси. Оволодіння культурою автономізації $\epsilon$ одним із напрямів універсалізації професійних і особистих рис керівника, що сприяє розумінню ним своєї свободи дій, своєї місії й призначення. Коли йдеться про культуру автономізації, то слід зрозуміти, на першому плані постає не лише управління інформаційними потоками, а реалізація творчого потенціалу особистості.

Культура автономізації керівника позашкільного закладу освіти $\epsilon$ вершиною його готовності до роботи в умовах невизначеності, - 
особливою ознакою сучасного життя представників освітньої галузі. Це твердження $€$ одним із наслідків розуміння нами культури автономізації як сукупності стилю креативного мислення керівника, що розкривається через такі ознаки: захопленість, ініціативність, винахідливість, аналітичність, ерудованість, інтелектуальність тощо. 3 огляду на це вкажімо на думку 0. Мармази про головну якість освітнього менеджера - готовність до самовдосконалення, саморозвитку, адже відмова від традиційного стилю управління вимагає перегляду мети розвитку, місії закладу освіти, що потребує оновлення знань та умінь у сфері менеджменту освіти [8].

Важливе місце в культурі автономізації керівника закладу позашкільної освіти займає наявність відповідних знань для процесу управління у мережевому середовищі, а саме: 1) про професійні і особистісні якості педагогічних працівників, їх організаційні здібності тощо; 2) про наявність умінь педагогічних працівників, які мають розвиватися у процесі роботи із вихованцями закладів позашкільної освіти; 3) про основні напрями системи знань у світлі педагогіки дозвілля, системи позашкільної освіти, сучасні інформаційні технології, що допомагають ефективно передавати, зберігати та поширювати нові знання для вирішення освітніх потреб вихованців; 4) про ефективні умови управління знання щодо виховання творчих особистостей, про особливості планування і прогнозування процесом опанування здобувачами позашкільної освіти відповідними компетентностями; 5) про основні функції керівника у забезпеченні можливості розробки нових програм для позашкілля; 6) про особливості підвищення якості позашкільної освіти і роботи у цьому напрямі із педагогічними працівниками закладу тощо.

У професійній діяльності директора позашкільного закладу освіти, як на нашу думку, важливим постає плекання креативних педагогів, яким для роботи із вихованцями свобода потрібна найбільш за все. Так, І. Грабовська, розкриваючи позиції, що пов'язані із менеджментом, в основі якого - креативність, вказує: «Нові якості креативних працівників не можна у готовому вигляді «придбати на ринку»; їх можна формувати, розвивати та ефективно використовувати завдяки реалізації унікальних індивідуальних спроможностей персоналу їхніх знань, умінь i досвіду, особистісних властивостей, які виявляються в ставленні до справи, в захопленості та інновативності» [4, c.45]. Вчена доводить, що підходи і інструменти управління знаннями мають допомогти виявити креативний потенціал 
працівників, визначити подальші напрями для його розвитку. Це можливо, як вважає автор, якщо використовувати їх компетенції, «сукупність професійних та особистісних характеристик (якостей) працівника, які створюють моделі його професійної поведінки, зумовлюють успішність його професійної діяльності та визначають конкурентоспроможність у професійному середовищі» [4, с. 45].

Формування культури автономізації у закладі позашкільної освіти залежить, в першу чергу, від самого керівника, його розвиненої здатності до самостійності, прагнення до діяльності у творенні норм діяльності, що змінюють і сприяють розвитку як працівників закладу, так і їх вихованців.

Культура автономізації передбачає оволодіння керівником спеціальних знань, умінь, навичок, що позначаються на управлінській діяльності, а саме:

- $\quad$ розуміння специфічності концепції автономії волі (І. Кант), іï особливого впливу на зведення мережевого середовища у закладі позашкільної освіти;

- орієнтація на самозаконодавчу активність у мережевому середовищі закладу позашкільної освіти так і поза його межами;

- вміння впливати на мотивацію працівників позашкільної освіти щодо покращання процесів творчого розвитку вихованців;

- здатність використовувати різні діалогові платформи для підтримки комунікаційних процесів та отримання інформації;

- готовність до активного розповсюдження взірців культури автономізації;

- відкритість до інноваційних ідей у галузі творення норм діяльності;

- вміння розуміти і сприймати культуру Іншої людини, враховуючи розширення кроскультурного простору тощо.

Таким чином, процеси удосконалення освітнього менеджменту у закладах позашкільної освіти вимагають розуміння культури автономізації у зведенні мережевого середовища, як складного поняття, в якому відображається послідовна ланка: прагнення до перетворення людини засобами творчості - вольовий прояв людини знаходження i затвердження нових правил, норм діяльності i поведінки. Вважаємо, що в нових умовах освітній менеджмент має враховувати позиції, що пов'язані із специфікою самого закладу позашкільної освіти, що вимагає від керівника нового розуміння самого процесу управління під час розробки і запровадження нових алгоритмів роботи із педагогічними працівниками. 
Зокрема, вбачаємо можливим впровадження спеціального алгоритму дій керівника позашкільного закладу освіти щодо розвитку культури автономізації, а саме: 1) прийняття рішення, що буде відображено у планах роботи педагогічних працівників, їх безпосередніх діях у цьому напрямі; 2) формування основних блоків (документальний, організаційний, науково-методичний, інформаційний), де будуть чітко представлені всі дії стосовно запровадження культури автономізації закладу із визначенням часових меж, які $є$ достатніми для досягнення цілей та виконання певного обсягу робіт; 3) організація обговорення основних блоків із педагогічними працівниками, затвердження відповідного плану роботи на педагогічній раді; 4) організація обговорень стосовно впровадження культури автономізації закладу із суб'єктами позашкільної освіти, колегами інших закладів; 5) розширення взаємовідносин між прихильниками ідей культури автономізації закладів позашкільної освіти під час зустрічей, організації конференцій тощо.

Отже, ефективний освітній менеджмент у позашкільних закладах можливий лише за умови наявності ефективного лідера, його спрямованості на підвищення самоефективності і ефективності працівників закладу в цілому. Закономірними у такому плані постають основні характеристики ефективного керівника, на які має бути спрямована увага, а саме: вміння розбудовувати мережі для управлінської діяльності, вміння аналізувати її ефективність; вміння розробляти алгоритми та за їх допомогою ефективно досягати поставлених цілей; вміння передбачати досягнення кожного педагога, результатів його роботи через аналіз його діяльності; вміння оцінити ситуацію, зробити висновки та втілити розумне управлінське рішення через комунікацію; вміння заохочувати ініціативи, спрямовані на зведення ефективної педагогічної діяльності в умовах розбудови мережевого суспільства; надання педагогічним працівникам бути креативними, розробляти та використовувати нові освітні програми тощо.

\section{Висновки}

Освітній менеджмент у закладах позашкільної освіти має полягати у керівництві багатьма процесами, які можуть мати як відкритий, так і прихований зміст. Бачити кожного педагога, його можливості та потенціал, із одного боку, та, із іншого - його проблеми і недоліки - ось, на чому можна фокусувати свою увагу керівнику закладів позашкільної освіти. За таких умов управління 
набуває гуманістичного характеру, розуміння людини, яка має вільно розвиватися і професійно зростати.

У розділі доведено, що сутність зростання та вільного розвитку має розумітися як синтез отриманих наукових знань та перенесення цих знань на мислення керівника, що вбудовує нові знання у систему отриманого управлінського досвіду і знаходить відображення у культурі автономізації закладу позашкільної освіти. Такий процес $\epsilon$ нелінійним, рухливим, що дозволяє керівникам закладів позашкільної освіти бути ефективними носіями освітніх традицій і новацій, дає змогу відповісти на різноманітні виклики, що виникають в управлінських практиках. У тому випадку, якщо намагатися створювати незворушну систему культурного зростання, то така система буде носити догматичний характер, де основними рисами буде жорсткість, упередженість до провадження будь-яких процесів.

Доведено, що для того, щоб діяльність керівника у цьому напрямі була успішною, слід застосовувати різноманітні ідеї, підходи (системний, аксіологічний, інформаційний), у тому числі основні позиції ліберальної педагогіки, яка передбачає зведення культури автономізації у позашкільному закладі освіти. У дослідженні розроблено спеціальний алгоритм дій для роботи керівника у цьому напрямі, а саме: 1) прийняття рішення щодо розвитку культури автономізації позашкільного закладу освіти, які будуть в основі планів роботи педагогічних працівників, їх безпосередній дій у цьому напрямі; 2) формування основних блоків (документальний, організаційний, науково-методичний, інформаційний), де буде чітко представлені всі дії стосовно запровадження культури автономізації закладу із визначенням часових меж, які $\epsilon$ достатніми для досягнення цілей та виконання певного обсягу робіт; 3) організація обговорення основних блоків із педагогічними працівниками, затвердження відповідного плану роботи на педагогічній раді; 4) організація обговорень стосовно впровадження культури автономізації закладу із суб'єктами позашкільної освіти, колегами інших закладів; 5) розширення взаємовідносин між прихильниками ідей культури автономізації закладів позашкільної освіти під час зустрічей, організації конференцій тощо.

Зрештою, зміна культури закладу є питанням лідерства, і справа буде полягати в тому, наскільки ефективними будуть дії керівника, як часто будуть задіяні до таких заходів потрібні педагогічні працівники, наскільки послідовною і планомірною буде така робота тощо. 
Трансформація культури автономізації закладу позашкільної освіти - складне завдання. Це вимагає інтелектуального управління, досвіду роботи у закладі освіти, ділової кмітливості, послідовності, емоційної стійкості. Забезпечувати постійний зв'язок та обмін інформацією, приймати рішення в основі яких - чесний діалог, є ефективним способом для початку руху закладів позашкільної освіти за автономію.

Таким чином, в межах розвитку позашкільної освіти формуються нові взаємовідносини, принципи, методи управління, визначається концепція освітнього менеджменту позашкільних закладів, що для сучасного суспільства постає важливим та перспективним.

\section{Література}

1. Бард А. Зодерквист Я. Netoкратия. Новая правящая элита и жизнь после капитализма. Санкт-Петербург : Стокгольмская школа экономики в Санкт-Петербурге, 2004. 252 с.

2. Барнард Ч. Функции руководителя. Власть, стимулы и ценности в организации. Москва : Litres, 2020.613 с.

3. Бондар А., Томанек, М. Менеджмент позашкільних навчальних закладів фізкультурно-спортивного напряму : монографія. Бидгош : Товариство наукової мережі спортивного права, 2018. 156 с.

4. Грабовська I.В. Сучасні аспекти управління знаннями в інноваційному менеджменті організації на засадах креативності. Вісник Хмельницького національного університету. Економічні науки. 2020. № 3. С. 42-47.

5. Кастельс М. Власть коммуникации. Москва : Изд. дом Высшей школы экономики, 2016.564 с.

6. Кастельс М. Информационная эпоха: экономика, общество и культура. Москва : ГУ ВШЗ, 2000. 608 с.

7. Кушнір I. Сучасний погляд на освітній менеджмент. Науковий вісник Мукачівського державного університету, 2020. Серія «Педагогіка та психологія». Випуск 1 (11). С. 28-30.

8. Мармаза О. І. Інноваційні підходи до управління навчальним закладом. Харків : Основа, 2014. 240 с.

9. Мармаза O.I. Менеджмент освітньої організації. Харків : ТОВ «Щедра садиба», 2017. 126 с.

10. Про затвердження Положення про програмно-апаратний комплекс «Автоматизований інформаційний комплекс освітнього менеджменту : Постанова Кабінету Міністрів України від 08.07.2021. URL: http://www.drs.gov.ua/wp-content/uploads/2021/07/dokument6610_0_19-21.pdf. (дата звернення: 13.10.2021). 
11. Про позашкільну освіту: Закон України № 2120-III від 07.12.2000. Відомості Верховної Ради України (ВВР), 2000, № 46, ст. 393.

12. Просіна О. Методика проведення SWOT-аналізу для стратегічного планування освітньої діяльності закладів позашкільної освіти в умовах пандемії. Теоретико-методичні проблеми виховання дітей та учнівської молоді. 2020. Вип. 24(2). С. 141-152.

13. Рижак Л. Високотехнологічне суспільство: запит на креативну людину. Вісник Львівського університету. Серія філософські науки. 2019. Вип. 22. С. 5-11.

14. Сбруєва А.А., Чистякова I. А., Самойлова Ю. І. Організаційнопедагогічні засади діяльності та тенденції розвитку інноваційних шкільних мереж Великої Британії та США : монографія. Суми : Сумський державний педагогічний університет імені А.С. Макаренка, 2019. 299 с.

15. Сопілко I. М. Становлення мережевого суспільства та питання кібербезпеки. Юридичний вісник Повітряне і космічне право : Наукові праці Національного авіаційного університету. 2016. № 1. С. 79-85.

16. Тихенко Л. В. Сучасні підходи до використання інформаційнокомунікаційних технологій у позашкільній освіті. Педагогічні науки: теорія, історія, інноваційні технології : науковий журнал Сумського державного педагогічного університету імені А. С. Макаренка. Суми : Вид-во СумДПУ імені А. С. Макаренка, 2011. № 1 (11). С. 367-374.

17. Чистякова I. Особливості управління європейськими академічними університетськими мережами. Порівняльно-педагогічні cmydiï. 2014. № 1. C. 56-60.

18. Bottery M. The Challenges of Educational Leadership. London : SAGE, 2004. $228 \mathrm{p}$.

19. Gunter H. Leaders and Leadership in Education. London : SAGE, 2001. $198 \mathrm{p}$.

20. Saba M., Rémur D., Gerbaix S. ICT implementation. Going beyond expectations? An essay of interpretation through competitive intelligence. International Strategic Management Review, Volume 2, Issue 1, 2014, P. 46-55. URL: https://doi.org/10.1016/j.ism.2013.11.001.

21. Spender J.-Ch. Modern Management: Origins and Development. International Encyclopedia of the Social \& Behavioral Sciences (Second Edition). New York: Elsevier, 2015, P. 675-681. URL: https:// doi.org/10.1016/B978-0-08-097086-8.73132-1. 